\title{
Passion Project Journaling in the EFL Classroom
}

\section{Judith Kambara}

\section{Okayama University}

\section{Reference Data:}

Kambara, J. (2020). Passion project journaling in the EFL classroom. In P. Clements, A. Krause, \& R. Gentry (Eds.), Teacher efficacy, learner agency. Tokyo: JALT. https://doi.org/10.37546/JALTPCP2019-45

Journaling activities in EFL classrooms, often based on prescribed journal prompts, are designed to elicit targeted grammar and vocabulary; however, prescribed prompts can be problematic because they lack a basis in reality and limit language structures available for use. After observing lackluster results with student journals based on prescribed topics, I introduced what I have termed passion project journaling in my 1st-year university English classes for general listening and speaking. Students were asked to journal extensively about topics in which they had a deep interest for the second of two 8-week terms in a semester-long course. Results showed marked increases in the average number of words per journal entry, range of language structures used, and topic engagement. Based on these results, I propose utilizing passion project journaling to increase students' sense of self-efficacy and to grant learners the agency to acquire new vocabulary and language structures in meaningful contexts.

英語学習コ一スにおけるジャーナル活動は，通常、教員が決めたジャーナル・トピックに基づき，学習目標である文法や語

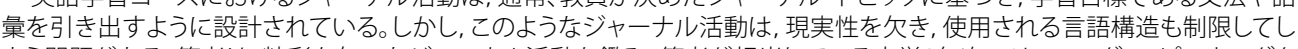

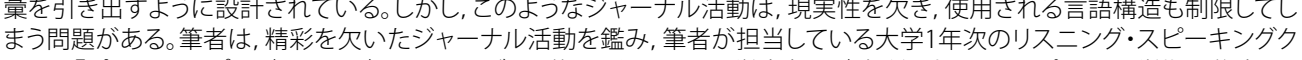

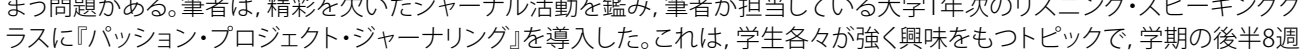

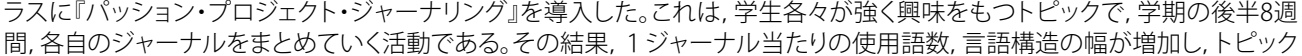

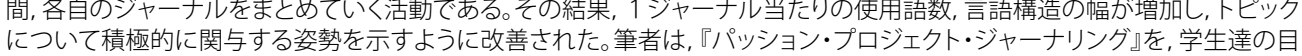
標達成意欲向上や、有意義な文脈て新しい語氈や文の構造を学ぶ主体的学習者とするために活用することを提晿する。 ournaling is a common practice in EFL classrooms, and prescribed journal prompts are often used to elicit the grammar and vocabulary taught in class lessons. The following is an example of a prompt targeting the simple present and vocabulary for expressing likes, dislikes, and favorites: Ask two friends about music, movies, or TV shows they like. Who is their favorite singer or actor? The results that 1 have observed when using prescribed journal prompts include limited engagement with topics, short responses, limited use of language structures, student boredom, and teacher boredom. There may be various reasons for poor journal results, including low motivation, limited vocabulary, not following instructions, and inadequate instruction about journaling (Nugent, 2019). Individual teachers must, therefore, reflect on both their instructional practices and students' abilities. I introduced passion project journals to explore whether giving students autonomy over their topics would mitigate these problems.

My inspiration for passion project journaling was a program called Passion Project Time at Kyoto International School, where I taught formerly (Kyoto International School, n.d.). Based on the Genius Hour Movement (geniushour.com), Passion Project Time gives students scheduled time for independent, long-term exploration of topics of their choosing. One 1st-grade student built a cardboard reading fort so that she could enjoy reading with her friends. One 4th-grade student made trading cards based on his passion for yōkai (mythical Japanese creatures), and another created flashcards so he could learn Thai to better communicate with his grandparents.

The goal of passion projects was for students to apply already acquired knowledge and skills to contexts that they were interested in. The 1st-grader who built the fort used math skills to calculate dimensions so that she and two friends could lie down while reading. The 4 th-graders researching yōkai and making Thai flashcards utilized internet research skills they had learned as well as language arts lessons about writing informational text to arrange the yōkai attributes and the meanings of Thai words in a pleasing and informative manner. 
Passion projects worked very well in the context of Kyoto International School, and teachers at the school found that students engaged with these projects and used multiple academic skills to accomplish the goals they had set for themselves. My hope was that allowing Japanese university students to write about something that they were passionate about would have a similar effect. I also hoped that students would be motivated to apply their existing knowledge of English vocabulary and grammatical structures and would feel motivated to learn new ones.

\section{Rationale: Prescribed Journals vs. Passion Project Journals}

Access to Language

Freire (2009) argued against the traditional "banking" concept of education in which teachers provide content which students receive and store as knowledge. This style of English education is still common in Japan in the form of yakudoku, which emphasizes explanations about English grammar in Japanese and direct translation of English passages into Japanese (Steele \& Zhang, 2016). By their first year of university, Japanese students have already acquired a wealth of English vocabulary and grammatical structures throughout their previous six years or more of schooling using this method. However, students have often had very few chances to use what they have learned in meaningful contexts (Steele \& Zhang, 2016). It was my belief that at the university level, further focused drilling through prescribed journal prompts targeting particular grammatical structures would simply serve to reinforce the banking style of education Furthermore, prescribed prompts might also constrain students' perceptions about the choice of language forms they are permitted to use. For example, using a prompt constraining students to the simple present means they are restricted from experiencing the full breadth and depth of their linguistic repertoires, something that has been shown to be essential for students to grow as language learners (Nation, 2013). Furthermore, student responses to prescribed prompts are almost always short and unimaginative.

I hoped that passion project journals would allow students to access the full range of language structures at their disposal and that allowing them to write about something they enjoyed would enable them to use the journaling process as a means of mediating their own language production (Lantolf, Thorne, \& Poehner, 2015). In these journals, students would use English to explain a topic that they were already familiar with using any forms available in their own linguistic repertoires, rather than simply produce the grammatical structures and vocabulary targeted by an assigned prompt. This more natural use of language, which has been shown to facilitate language learning (Swain, 2000,2009 ), would allow students to engage with the language in a meaningful way.

\section{Agency and Self-Efficacy}

Language instruction is often designed without the external goals of individual students in mind (Cook, 2002). This criticism is especially true for prescribed journal prompts since the topics used to elicit targeted grammatical structures and vocabulary are rarely relevant to students' lives. Previous studies have shown that effective learning happens when students are able to engage with topics they can relate to and when they are given agency over their learning (Peterson, 2009; Shor, 2009). This kind of agency provides task-ownership and facilitates motivation (Muir \& Dornyei, 2013). Thus, requiring learners to journal about topics they are not interested in or are unfamiliar with may present barriers to their sense of agency resulting in boredom and limited engagement with the topic. In contrast, passion project journaling allows students the autonomy to choose their topics and to learn the vocabulary and grammar that they feel are useful for their particular situations.

According to Bandura (1982), learners who perceive a high degree of self-efficacy (i.e., the ability to produce an intended result) are more likely to view tasks positively and to put more effort into accomplishing even difficult tasks. Furthermore, those who doubt their self-efficacy tend to view tasks with foreboding and may even misjudge tasks as being more difficult than they actually are. Since language learners often doubt their ability to communicate in the target language (Harumi, 2011), prescribed journal topics requiring students to write in their second language about unfamiliar topics present a double barrier to students' feelings about self-efficacy. However, allowing students to journal about topics on which they are experts or are highly motivated to investigate can remove one of these barriers and enable them to focus on communicating their chosen topic in the target language.

\section{Student-Owned Narratives}

Journals based on prescribed prompts ignore what Moll, Amanti, Neff, and Gonzalez (1992) called learners' "funds of knowledge." Journaling based exclusively on prescribed prompts relegates students to telling a single story (i.e., that which the teacher has designated as worth telling; Behizadeh, 2014). While prescribed prompts do afford some room for individuality (e.g., students' favorite types of music), students are still restricted to writing about a topic decided by the teacher. When learners do not have the agency to tell their own stories, their self-efficacy may be limited.

An additional consequence of assigning prescribed prompts is that teachers set themselves up to read multiple variations on the same response. Teachers often forget that students possess experiences, interests, and even expertise in a variety of fields. 
Through passion project journals, I have learned that some of my students are sculptors, experienced farmers, or are earning money as website developers. Therefore, granting students the agency to write about topics of their choosing has the added perk of mitigating teacher boredom by providing a unique story in every journal.

\section{Basis in Reality}

Another issue with prescribed journals is that they lack a basis in reality. In real-life situations, people hardly ever have conversations that mimic journal prompts such as "What kinds of clothes do you like to wear?" and "What's your daily schedule like?" Certainly, these questions, especially the latter, do arise occasionally; however, they are quickly answered and are not expected to be the basis for a deep and lasting conversation. Consequently, most journal responses based on prescribed prompts tend to be short.

When students are forced to write at length about these types of prompts, their responses can take the form of essay-type treatises. Such lengthy responses would be considered socially awkward in real-world settings because they violate Grice's maxim of quantity (i.e., that an interlocutor's contribution to a conversation should neither convey too much nor too little information for the situation; Meyer, 2014). In other words, such responses lack reality because they would not be acceptable outside of the classroom setting. In contrast, passion project journaling allows students to develop a topic on which they might converse deeply with a real interlocutor outside of the classroom. The ability to develop responses in this way allows students to go beyond the exercise itself and to imagine their possible selves in real-world situations, something that has been shown to be beneficial to language learning (Dornyei \& Chan, 2013; Duff, 2012; Markus \& Nurius, 1986; Muir \& Dornyei, 2013).

\section{Research Questions}

Building on previous studies showing the benefits of granting students agency in choosing their own topics, as well as on my own teaching experiences, I wanted to see how allowing university students the freedom to choose their journal topics would affect their language production and engagement with the topic. Accordingly, this study was guided by three research questions:

1. How did the ability to choose their own topics affect the amount of words students were able to write?

2. How did the ability to choose their own topics affect the quality of students journals?
3. How did the ability to choose their own topics affect how students were able to engage with the content of their journals?

Method

Context and Participants

The participants were 44 Japanese 1st-year undergraduate students enrolled in a required English course in listening and speaking for general purposes at a national public university in Japan. All students fell within the CEFR A2 range. The students were distributed between two classes. Students in Class $1(n=20)$ belonged to the faculty of social sciences and had an estimated TOEIC range of 243-379. Students in Class $2(n=24)$ belonged to the faculty of natural sciences and had an estimated TOEIC range of 455478. TOEIC ranges were estimated by the university based on the students' GTEC scores. The university has four 8-week terms. The classes in this study spanned Terms 3 and 4 . Each class met once per week for 120 minutes for 16 weeks. Students were graded at the end of each term.

\section{Introducing Passion Project Journals}

During Term 3, students were required to write one journal entry each week for homework. Journal entries were based on prescribed prompts designed to elicit that lesson's grammar and vocabulary. Students were told to write at least 50 words per entry in a notebook designated for journaling. Journals were checked periodically for completion and were collected for grading at the end of the term.

During Term 4, students were assigned passion project journals. Students were asked to write about a single topic for eight weeks. Students were told that their topic should be one about which they were passionate (i.e., one which they already knew a great deal about or had a keen interest in learning about, such as a hobby or a skill they might need in the future). Students were asked to imagine conversing with someone about their topic while writing. Possible scenarios for these conversations, such as meeting someone for the first time and discovering shared interests or mentoring a colleague in their area of expertise, were given. Students were told to write as much as they wanted and that no minimum word count was required. Students were also encouraged to make multiple entries per week, to define new words and topic-specific terms (e.g., framing in photography), and to include illustrations. I showed students an example of a journal entry I had written describing my passion for photography to demonstrate what they were expected to do. 


\section{Assessing the Journals}

\section{Word Count}

Average word count per entry for each term and the percent increase from Term 3 to Term 4 were calculated for each class and for both classes combined. Each journal entry was counted manually, and data for each student was entered in Microsoft Excel.

As previously explained, students were encouraged to make multiple entries per week during Term 4. Since I had made it clear that I expected students to write as experts or with deep interest in a topic, I explicitly granted them permission to come and go during each week's journal entry. I hoped that the ability to do this would aid their writing endeavors by helping them avoid fatigue. Therefore, each week's worth of writing in Term 4 was considered one collective entry.

An analysis of the word count over the two terms showed that the average words per journal entry increased from Term 3 to Term 4 . Eighty-five percent of students in Class 1 and $67 \%$ of students in Class 2 showed increases. Table 1 shows that the average percent increase was higher for Class 2.

Table 1. Change in Average Words Per Entry

\begin{tabular}{lccccc}
\hline Class & \multicolumn{2}{l}{ Words Per Entry: Term 3 } & \multicolumn{2}{c}{ Words Per Entry: Term 4 } & $\begin{array}{c}\text { Average \% } \\
\text { Increase }\end{array}$ \\
\cline { 2 - 6 } & Mean & SD & Mean & SD & \\
\hline Class 1 $(\boldsymbol{n}=\mathbf{2 0})$ & 54.69 & 18.15 & 79.13 & 30.75 & $51.52 \%$ \\
Class 2 $(\boldsymbol{n}=\mathbf{2 4})$ & 61.83 & 23.76 & 92.24 & 58.01 & $74.39 \%$ \\
Both $(\boldsymbol{n}=\mathbf{4 4})$ & 58.58 & 21.46 & 86.00 & 47.50 & $63.73 \%$ \\
\hline
\end{tabular}

Furthermore, the increase in word count was more pronounced in students who had not written much during Term 3 (see Table 2). Of the fourteen students who did not meet the 50-word requirement in Term 3, all but four students raised their average words per entry to above 50 words in Term 4 despite the fact that there was no minimum requirement.
Table 2. Progress of Students not Meeting Term 3 Minimum Words Per Entry

\begin{tabular}{lccccc}
\hline Class & \multicolumn{2}{c}{ Words Per Entry: Term 3 } & \multicolumn{2}{c}{ Words Per Entry: Term 4 } & $\begin{array}{c}\text { Average \% } \\
\text { Increase }\end{array}$ \\
\cline { 2 - 6 } & Mean & SD & Mean & SD & \\
\hline Class 1 $(\boldsymbol{n}=\mathbf{9})$ & 37.42 & 7.42 & 61.02 & 17.49 & $63.07 \%$ \\
Class 2 $(\boldsymbol{n}=\mathbf{5})$ & 33.92 & 8.81 & 139.17 & 98.44 & $310.29 \%$ \\
Both $(\boldsymbol{n}=\mathbf{1 4})$ & 36.17 & 7.80 & 88.93 & 68.41 & $145.87 \%$
\end{tabular}

\section{Journal Quality}

Four criteria were measured to determine journal quality-content engagement, grammar, language variation, and comprehensibility - and each criterion was scored using a 5-point rubric (Table 3). I made every effort to apply the categories objectively to each entry. The journal scores were part of the students' final grades.

A comparison of the quality of Term 3 and Term 4 journals showed that students made improvements in content engagement and language variation as well as in their overall journal scores (Figure 1). Class 2 showed higher gains in all three areas than did Class 1, and the greatest gains in both classes were made in language variation. However, both classes showed decreases in grammar and comprehensibility, with Class 2 showing a greater decrease in both areas.

\section{Discussion}

Word Count

With regard to the first research question, students clearly had more to say in the passion project journals than in the journals based on prescribed prompts. This is not surprising since these journals were written about topics more appropriate to lengthy responses and students chose topics about which they were passionate. However, the fact that students were not simply writing longer entries was even more interesting. They were also showing more engagement with the topic and, consequently, the process of producing output -in this case writing - which has been shown to assist language acquisition (Swain, 1995).

One student from Class 2 who had a 40.17\% increase in word count (from 130 to 183 average words per entry), already wrote prolifically and supplied appropriate details and 
examples in Term 3. In Term 4, however, he wrote about civil engineering methods for controlling flood and sediment disasters. His explanations and illustrations about different river embankment construction types and their functions were particularly informative and highlighted his future goal of contributing to Japan's disaster management.

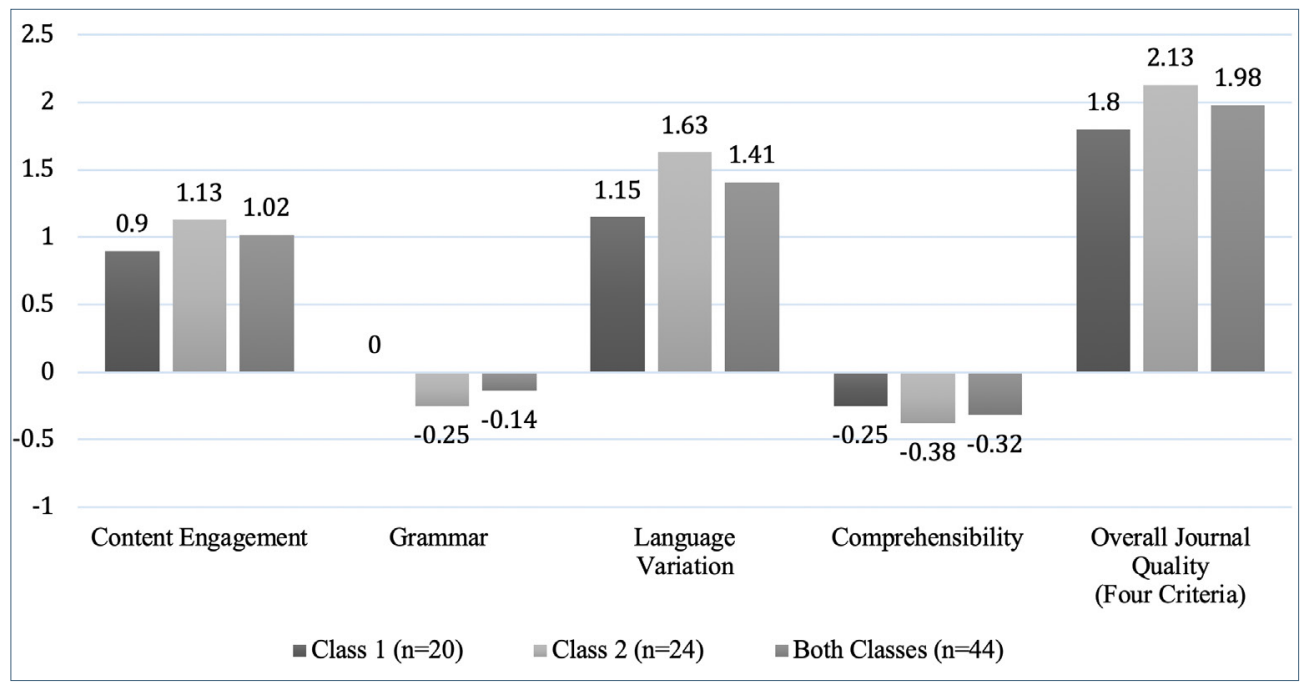

Figure 1. Average point changes in journal quality from Term 3 to Term 4.
As mentioned previously, most students who did not meet the 50-word minimum in Term 3 exceeded 50 words per entry in Term 4 (Table 2). One student from this group wrote extensively about fishing and which lures to use in different conditions. In each entry, he included detailed drawings showing how various lures move through the water to entice fish. His average word count per entry increased from 42.4 to 209.17 -a 392.16\% increase. Another student who increased from 41.17 to 113.83 words per entry - a 176\% increase-wrote about his love of photographing rare birds in the forest near his house. The student with the most dramatic increase wrote about his deep interest in the $\mathrm{C}$ computer programming language. He went from 34 words per entry in Term 3 to 271.33 words per entry in Term $4-\mathrm{a} 698.02 \%$ increase. He also included diagrams and several definitions per entry, indicating that he may have learned a great deal of domain-specific vocabulary. This high level of engagement with topics may indicate that some students experienced a heightened level of task engagement, described by Muir and Dornyei (2013) as directed motivational currents, in which people become deeply engrossed in an activity in a way that facilitates learning.

\section{Journal Quality}

With regard to the second research question, improvements in journal quality, passion project journals were of better quality than the prescribed journals. The difference between the quality of these two types of journals is most evident in the category of language variation. These gains seem to suggest that students had been constrained by

Table 3. Journal Quality Rubric

\begin{tabular}{|c|c|c|c|c|c|}
\hline & 1 & 2 & 3 & 4 & 5 \\
\hline Content Engagement & $\begin{array}{l}\text { Superficial / no details. } \\
\text { Little interest in topic. }\end{array}$ & $\begin{array}{l}\text { Superficial details. Some } \\
\text { interest in topic. }\end{array}$ & $\begin{array}{l}\text { Moderate details. Interest in } \\
\text { topic. }\end{array}$ & $\begin{array}{l}\text { Good details. Clear interest } \\
\text { in topic. }\end{array}$ & $\begin{array}{l}\text { Significant details. } \\
\text { Enthusiastic about topic. }\end{array}$ \\
\hline $\begin{array}{l}\text { Grammar (tense, s-v } \\
\text { agreement, etc.) }\end{array}$ & $\begin{array}{l}\text { Frequent inappropriate } \\
\text { grammar. }\end{array}$ & $\begin{array}{l}\text { Many recurring } \\
\text { mistakes. }\end{array}$ & $\begin{array}{l}\text { Mostly appropriate grammar. } \\
\text { Some recurring mistakes. }\end{array}$ & $\begin{array}{l}\text { Mostly appropriate grammar. } \\
\text { No recurring mistakes. }\end{array}$ & $\begin{array}{l}\text { Excellent grammar. } \\
\text { Minimal mistakes. }\end{array}$ \\
\hline $\begin{array}{l}\text { Language Variation } \\
\text { (grammar structures \& } \\
\text { vocabulary) }\end{array}$ & $\begin{array}{l}\text { No variety. One grammar } \\
\text { structure per entry. Simple } \\
\text { vocabulary. }\end{array}$ & $\begin{array}{l}\text { Some variety of grammar } \\
\text { / vocabulary attempted. }\end{array}$ & $\begin{array}{l}\text { Some variety of grammar / } \\
\text { vocabulary demonstrated. }\end{array}$ & $\begin{array}{l}\text { Good variety of grammar / } \\
\text { vocabulary demonstrated. }\end{array}$ & $\begin{array}{l}\text { Wide variety of grammar / } \\
\text { vocabulary demonstrated. }\end{array}$ \\
\hline Comprehen-sibility & $\begin{array}{l}\text { Overall meaning often } \\
\text { unclear. }\end{array}$ & $\begin{array}{l}\text { Overall meaning } \\
\text { sometimes unclear. }\end{array}$ & $\begin{array}{l}\text { Some points hard to understand. } \\
\text { Overall meaning clear. }\end{array}$ & Meaning always clear. & Meaning extremely clear. \\
\hline MFRONT & $\triangle \mathrm{PREVIO}$ & PAGE & XT PAGE > & ONLINE & ULL SCREEN \\
\hline
\end{tabular}


each week's target grammar and vocabulary in the Term 3 prescribed topic journals and that they attempted to access a wider range of language structures in Term 4 . This seems to indicate that one focus of passion project journaling-allowing students to access the full range of vocabulary and grammar structures in their repertoires-was accomplished.

One potential issue was the modest decrease that was shown in both grammar and comprehensibility; however, no student's scores in either area dropped to a point at which their message could not be understood. These drops were likely caused by an increase in the amount that students wrote. Furthermore, their ability to write about something they enjoyed enabled them to use a greater variety of language structures, some of which they had less control over than the simple grammatical structures they used when writing about the prescribed prompts. Also, researchers hold that making grammatical mistakes is an important part of becoming more proficient in a language (Gass \& Mackey, 2006; Lightbown \& Spada, 2013). When students push themselves to use new or unfamiliar grammatical and lexical forms to explain something to an interlocutor, they may begin to notice the forms they need to acquire to become more proficient speakers (Gass \& Mackey, 2006; Swain, 1995).

\section{Content Engagement}

With regard to the final research question, it seems that the passion project journals did result in increased engagement. As alluded to in the discussion about word count, most of the topics students wrote about in Term 4 were very interesting. One student wrote about her dream of becoming a café owner. She detailed the skills and knowledge that she would need to learn to become successful as well as her plan for doing so. Another memorable journal about sculpting was not only informative but also particularly touching. In addition to sharing sculpting techniques and illustrations of her artwork, this student also revealed that sculpting has been a form of therapy on her journey to recovering from experiences with bullying.

It is important to talk about content engagement and language variation together, particularly with regard to Class 2. Class 2, the natural sciences group, demonstrated greater gains in both areas than did Class 1 , the social sciences group. Two students from Class 2 demonstrated 3-point gains in both content engagement and language variation, while another student gained 4 points in content engagement and 3 points in language variation. Research indicates the importance of developing the language structure and vocabulary that allows learners to express their feelings and to talk about topics central to their sense of self and states that being unable to do so can lead to frustration (Pavlenko \& Lantolf, 2000). General-purpose English conversation textbooks deal predominately with broad topics related to daily life and living environments, while technical topics related to science and engineering are often ignored (Siegel, 2014). This may be demotivating for science students (Apple, Falout, \& Hill, 2013). The higher overall gains in journal quality for Class 2 as well as gains in content engagement, language variation, and word count may indicate that passion project journaling extends a particular level of agency to students in technical fields by providing an outlet for discussing topics that are important to them as well as the means of developing the language for doing so.

\section{Conclusion}

This study shows that the ability of students to choose their journal topics resulted in more words written per journal entry, higher journal quality, and increased topic engagement. Furthermore, the passion project journals were a pleasure to read. Most importantly, I gained new insights into my students' abilities, interests, and aspirations.

While this study of passion project journals showed that this type of student-owned writing yielded very different and more pleasing results, it should be noted that it has some limitations. Because there was no control group, it is difficult to ascertain whether increases in word count might also be attributed to increased experience with journal writing in Term 4. Another limitation is the relatively small number of students in the study. Finally, I was the only journal evaluator, and the rubric was based on selfdeveloped criteria which were admittedly subjective. Different results might have been obtained if other teachers had been involved or if more objective scoring criteria had been used.

However, I think that increased language facility through passion project journaling shows the potential that this type of journaling has. In the future, it would be good to engage in the same type of research with a control group and to use passion project journals with a greater variety of language proficiency levels. Furthermore, students' perceptions about their learning should be explored. A post-course survey could yield insights into how cultural and individual learning preferences might align or be at odds with teacher perceptions about whether learning occurred. Finally, it would be beneficial to look at the effects of passion project journals in writing classes, where there is more of a focus on written output.

Passion project journaling is a tool that can be used to help students engage with language via topics they are passionate about by using previously learned language skills for authentic communication. In so doing, students can develop a sense of task ownership and self-efficacy that may motivate them to acquire new language skills. As 
students become engaged with their topics they write more prolifically. This increased output spurs noticing of language structures that need improvement. Additionally, teachers can use passion project journals to get acquainted with their students on a much deeper level-indeed, to see them as people with hopes and dreams, as experts, and as cocreators of knowledge rather than as receptacles in which to deposit knowledge. Passion project journals, therefore, have implications for informing instruction that is responsive to individual learners' needs and abilities.

\section{Bio Data}

Judith Kambara holds an MA in applied linguistics and is a part-time lecturer at Okayama University. A U.S.-licensed language arts and social studies teacher with over 10 years of classroom experience, her teaching practice focuses on creating an equitable and interactive learning environment. Her research interests include critical pedagogy, authentic learning, student and teacher beliefs about learning and teaching methods, and human rights education.

\section{References}

Apple, M., Falout, J., \& Hill, G. (2013). Exploring classroom-based constructs of EFL motivation for science and engineering students in Japan. In M. Apple, D. Da Silva, \& T. Fellner (Eds.), Language learning motivation in Japan (pp. 54-68). Buffalo, NY: Multilingual Matters. https://doi org/10.21832/9781783090518-006

Bandura, A. (1982). Self-efficacy mechanism in human agency. American Psychologist, 37(2), 122 147. https://doi.org/10.1037/0003-066X.37.2.122

Behizadeh, N. (2014). Mitigating the dangers of a single story: Creating large-scale writing assessments aligned with sociocultural theory. Educational Researcher, 43(3), 125-136. https://doi. org/10.3102/0013189X14529604

Cook, V. (2002). Language teaching methodology and the L2 user perspective. In V. Cook (Ed.) Portraits of the L2 user (pp. 325-344). Buffalo, NY: Multilingual Matters Ltd. https://doi. org/10.21832/9781853595851-015

Dornyei, Z., \& Chan, L. (2013). Motivation and vision: An analysis of future L2 self images, sensory styles, and imagery capacity across two target languages. Language Learning, 63(3), 437-462. https://doi.org/10.1111/lang.12005

Duff, P. (2012). Identity, agency, and second language acquisition. In S. Gass \& A. Mackey (Eds.), The Routledge handbook of second language acquisition (pp. 410-426). New York, NY: Routledge. https://doi.org/10.4324/9780203808184
Freire, P. (2009). From pedagogy of the oppressed. In A. Darder, M. Baltodano, \& R. Torres (Eds.), The critical pedagogy reader (2nd ed.) (pp. 52-60). New York, NY: Routledge.

Gass, S. \& Mackey, A. (2006). Input, interaction, and output: An overview. AlLA Review, 19(1), 3-17. https://doi.org/10.1075/aila.19.03gas

Harumi, S. (2011). Classroom silence: Voices from Japanese EFL learners. ELT Journal, 65(3), 260269. https://doi.org/10.1093/elt/ccq046

Kyoto International School. (n.d.). Passion projects. Retrieved from https://www.kis.ac.jp/studentlife/passionprojects/

Lantolf, J., Thorne S., \& Poehner, M. (2015). Sociocultural theory and second language development. In B. VanPatten \& J. Williams (Eds.), Theories in second language acquisition: An introduction (2 ${ }^{\text {nd }}$ ed.) (pp. 207-226). New York, NY: Routledge. https://doi org/10.4324/9780203628942

Lightbown, P. and Spada, N. (2013). How languages are learned (4th ed.). Oxford, England: Oxford University Press.

Markus, H., \& Nurius, P. (1986). Possible selves. American Psychologist, 41(9), 954-969. https://doi. org/10.1037/0003-066X.41.9.954

Meyer, C. (2014). Introducing English linguistics. Cambridge, England: Cambridge University Press. https://doi.org/10.1017/cbo9780511757822

Moll, L., Amanti, C., Neff, D., \& Gonzalez, N. (1992). Funds of knowledge for teaching: Using a qualitative approach to connect homes and classrooms. Theory into Practice, 31(2), 132-141. https://doi.org/10.1080/00405849209543534

Muir, C., \& Dornyei, Z. (2013). Directed motivational currents: Using vision to create effective motivational pathways. Studies in Second Language Learning and Teaching, III(3), 357-375. https:// dx.doi.org/10.14746/ssllt.2013.3.3.3

Nation, P. (2013). What should every EFL teacher know? Seoul, Korea: Compass Publishing.

Nugent, P. (2019). Journaling with EFL students: A case study. The Center for the Study of English Language Teaching Journal, 7, 43-70. Fukuoka Jogakuin University English Education and Research Center. Retrieved from http://hdl.handle.net/11470/777

Pavlenko, A. \& Lantolf, J. (2000). Second language learning as participation and the (re)construction of selves. In J. Lantolf (Ed.), Sociocultural theory and second language learning (pp. 155-177). Oxford, England: Oxford University Press.

Peterson, R. (2009). Teaching how to read the world and change it: Critical pedagogy in the intermediate grades. In A. Darder, M. Baltodano, \& R. Torres (Eds.), The critical pedagogy reader ( $2^{\text {nd }}$ ed., pp. 305-323). New York, NY: Routledge.

Shor, I. (2009). What is critical literacy? In A. Darder, M. Baltodano, \& R. Torres (Eds.), The critical pedagogy reader (2 ${ }^{\text {nd }}$ ed., pp. 282-304). New York, NY: Routledge. 
Siegel, A. (2014). What should we talk about? The authenticity of textbook topics. ELT Matters, 68(4), 363-375. https://doi.org/10.1093/elt/ccu012

Steele, D., \& Zhang, R. (2016). Enhancement of teacher training: Key to improvement of English education in Japan. Procedia-Social and Behavioral Sciences, 217, 16-25. https://doi.org/10.1016/j. sbspro.2016.02.007

Swain, M. (1995). Three functions of output in second language learning. In G. Cook \& B.

Seidlhofer (Eds.) Principle \& practice in applied linguistics: Studies in honour of H.G. Widdowson (pp. 125-144). New York: Oxford University Press.

Swain, M. (2000). The output hypothesis and beyond: Mediating acquisition through collaborative dialogue. In J. P. Lantolf (Ed.) Sociocultural theory and second language learning (pp. 97-114). Oxford, England: Oxford University Press.

Swain, M. (2009). Languaging, agency, and collaboration in advanced second language proficiency. In H. Byrnes (Ed.) Advanced language learning: The contribution of Halliday and Vygotsky (pp. 95108). London, England: Bloomsbury. https://doi.org/10.5040/9781474212113.ch-004 